$\cdot 1-$

$$
\text { DOEFETC/C- }-98 / 7293
$$

\title{
Reducing the Manufacturing Cost of Tubular SOFC Technology
}

Raymond A. George ${ }^{a 1}$ and Norman F. Bessette ${ }^{\text {b2 }}$ CONF- 9709197 aSOFC Power Generation, Westinghouse Electric Corporation, Pittsburgh,

Pennsylvania 15235

'SOFC Power Generation, Cell Manufacturing Development, Westinghouse Electric Corporation, Pittsburgh, Pennsylvania 15235.

Abstract

RECEIVED DEC 081997

In recent years, Westinghouse Electric Corporation has made great strides in 1 advancing tubular solid oxide fuel cell (SOFC) technology towards commercialization by the year 2001. In 1993, Westinghouse initiated a program to develop a "MWeClass" (1-3 MWe) pressurized SOFC (PSOFC)/gas turbine (GT) combined cycle power system for distributed power applications because of its 1) ultra-high efficiency $\left(-63 \%\right.$ net $\left.\left.\mathrm{AC/LHV} \mathrm{CH}_{4}\right), 2\right)$ its compatibility with a factory packaged, minimum site work philosophy, and 3) its cost effectiveness. Since then two cost studies on this market entry product performed by consultants to the U.S. Department of Energy have confirmed Westinghouse cost studies that fully installed costs of under $\$ 1300 / \mathrm{kWe}$ can be achieved in the early commercialization years for such small PSOFC/GT power systems. The paper will present the results of these cost studies in the areas of cell manufacturing cost, PSOFC generator

1 Corresponding author. Fax: (412) 256-2012, e-mail: georgera@westinghouse.com Present address, Westinghouse Electric Corporation, Science and Technology Center, 1310 Beulah Road, Pittsburgh, Pennsylvania 15235, USA.

2 Co-author. Fax: (412) 256-5504, e-mail: bessetnf@westinghouse.com

Present address, Westinghouse Electric Corporation, Science and Technology Center, 1310 Beulah Road, Pittsburgh, Pennsylvania 15235, USA. 


\section{DISCLAIMER}

This report was prepared as an account of work sponsored by an agency of the United States Government. Neither the United States Government nor any agency thereof, nor any of their employees, makes any warranty, express or implied, or assumes any legal liability or responsibility for the accuracy, completeness, or usefulness of any information, apparatus, product, or process disclosed, or represents that its use would not infringe privately owned rights. Reference herein to any specific commercial product, process, or service by trade name, trademark, manufacturer, or otherwise does not necessarily constitute or imply its endorsement, recommendation, or favoring by the United States Government or any agency thereof. The views and opinions of authors expressed herein do not necessarily state or reflect those of the United States Government or any agency thereof. 
manufacturing cost, balance-of-plant (BOP) cost, and system installation cost. In addition, cost of electricity calculations will be presented.

Keywords: SOFC; SOFC/GT; Manufacturing Cost

\section{Introduction}

Over the past 10 years the Westinghouse SOFC development team has made major progress towards reducing SOFC manufacturing costs $(\$ / \mathrm{kWe})$. This paper describes the important technology breakthroughs, presents the results of a cost study of a 3 MWe pressurized SOFC (PSOFC)/gas turbine (GT) power system performed in 1996 by Westinghouse and two consultants (A. D. Little and Spencer Management) to the U.S. Department of Energy and updated by Westinghouse in 1997, and compares the cost of electricity (COE) of such a system with that of the most advanced small ( $<5 \mathrm{MWe}$ ) gas turbine generator currently under development.

\section{SOFC Technology Status}

Over the past 10 years, the Westinghouse tubular SOFC design has evolved from a zirconia porous support tube (PST) type with an active length of $30 \mathrm{~cm}$ and active area of $113 \mathrm{~cm}^{2}$ to an air electrode supported (AES) type with an active length of $150 \mathrm{~cm}$ and active area of $834 \mathrm{~cm}^{2}$. Figure 1 illustrates these two design types and Table 1 presents a comparison of their design parameters. As can be seen from Table 1 the cell power output has been increased by an order of magnitude over the last 10 years, resulting in one-tenth the number of cells needed for a given cell stack power output. Furthermore, the zirconia PST has been eliminated resulting in a 
lower cost and more reliable cell design. The $150 \mathrm{~cm}$ AES cell is now a proven design with over 60 cells tested including a 48 -cell bundle test, and over 1300 cells manufactured in our \$13 million Pilot Manufacturing Facility (PMF). The cell stack for the EDB/ELSAM (a Dutch and Danish Utility Consortium) $100 \mathrm{kWe}$ field unit contains 1152 of these cells. The unit factory test is expected to begin in early October, 1997 and the site test in Arnhem, The Netherlands is expected to begin in December 1997.
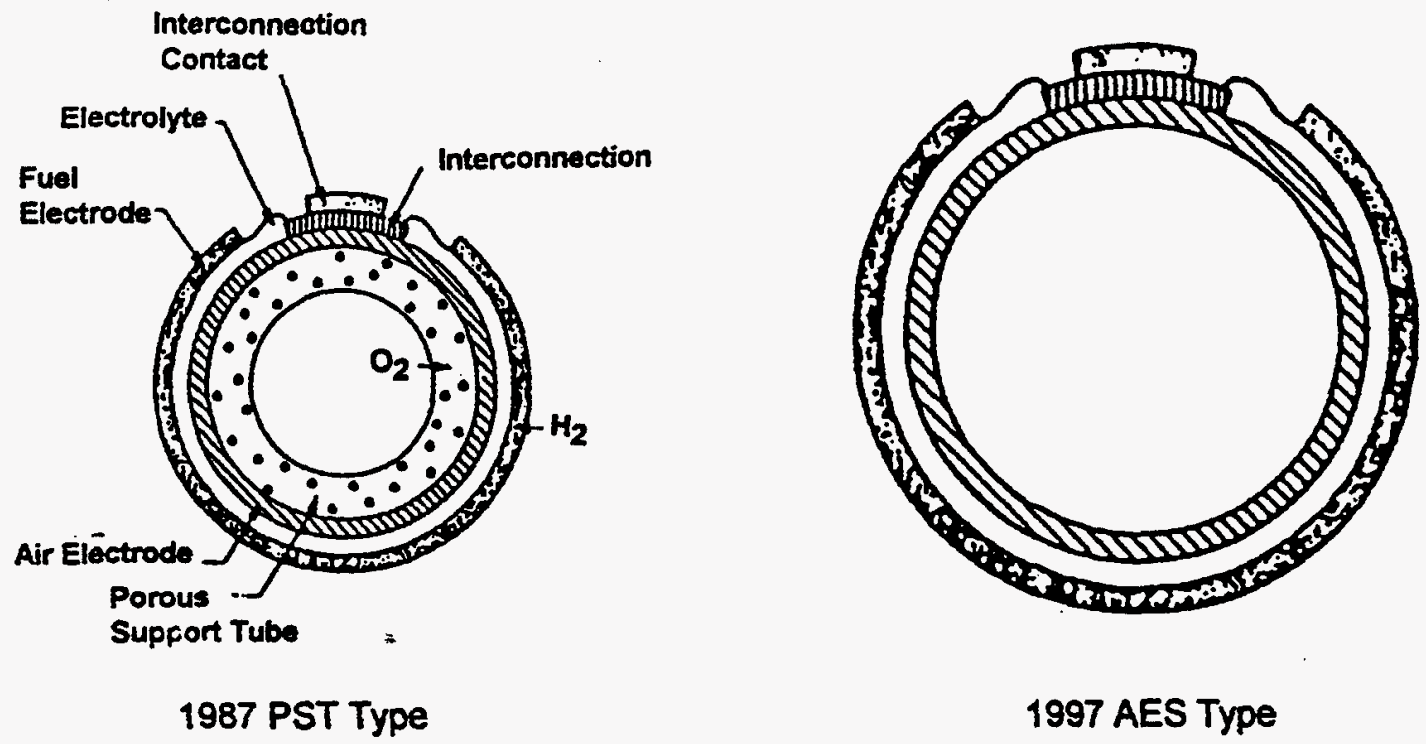

1997 AES Type

Fig. 1. Tubular SOFC Design Evolution. 


\begin{tabular}{|l|c|c|}
\hline & 1987 PST Type & 1997 AES Type \\
\hline Cell OD $(\mathrm{cm})$ & 1.52 & 2.23 \\
\hline Cell active length $(\mathrm{cm})$ & 30 & 150 \\
\hline Cell total length $(\mathrm{cm})$ & 42 & 168 \\
\hline Cell active area $\left(\mathrm{cm}^{2}\right)$ & 113 & 834 \\
\hline PST ID/OD $(\mathrm{cm})$ & $0.89 / 1.29$ & N.A.N.A. ${ }^{*}$ \\
\hline AE ID/OD $(\mathrm{cm})$ & $1.29 / 1.49$ & $1.76 / 2.20$ \\
\hline IC length/width $(\mathrm{cm})$ & $30 / 1.1$ & $150 / 1.1$ \\
\hline IC thickness $(\mu \mathrm{m})$ & 40 & 100 \\
\hline EL thickness $(\mu \mathrm{m})$ & 40 & 40 \\
\hline FE thickness $(\mu \mathrm{m})$ & 100 & 100 \\
\hline Max. power @ 1 atm (watts) & 20 & 210 \\
\hline & & \\
\hline${ }^{*}$ Not applicable & & \\
\hline
\end{tabular}

Table 1. Tubular SOFC Design Parameter Comparison

The cell scale-up to commercial size has been completed, and the emphasis is now on materials cost reduction, development of low cost manufacturing processes, and supplier development. Since the air electrode tube constitutes $92 \%$ of the weight of the finished cell, the material cost reduction program is focused on the air electrode precursor materials (i.e., the raw materials which are used for synthesizing doped $\mathrm{LaMnO}_{3}$ ). In particular, the focus is on qualifying lower purity precursor materials, which will reduce the air electrode precursor materials cost in large volume from $\$ 25 /$ cell to $\$ 6 /$ cell. Concerning the development of low cost manufacturing processes, the focus over the last 5 years has been the substitution of lower cost ceramic processes, such as plasma spray and sintering, for 
electrochemical vapor deposition (EVD). Five years ago, all three thin film layers (interconnection, electrolyte and fuel electrode) were deposited by EVD. Since 1992 the interconnection has been deposited by plasma spray in production (over 2500 cells produced with plasma sprayed interconnections). In addition, over 20 cells have been made in the laboratory with sintered fuel electrodes, and Westinghouse expects to initiate production of sintered fuel electrode cells in the PMF by June, 1998. It is anticipated that the first production line in the Commercial Manufacturing Facility (CMF) will consist of the following thin film deposition processes: plasma spray for the interconnection, EVD for the electrolyte and slurry dipping/sintering for the fuel electrode. Finally, for the last 2 years, Westinghouse has been developing strategic partners for the supply of ceramic materials and components. Praxair Surface Technologies, for example, is collaborating with Westinghouse to produce 1) doped $\mathrm{LaCrO}_{3}$ powder for plasma spraying the interconnection, 2) doped $\mathrm{LaMnO}_{3}$ powder for air electrode tubing making, and 3) sintered air electrode tubes.

\section{3. $3 \mathrm{MWe}$ PSOFC/GT Power System Description}

For the purpose of the cost study performed by Westinghouse, A. D. Little, and Spencer Management, Westinghouse performed a conceptual design of a $3 \mathrm{MWe}$ PSOFC/GT power system. Table 2 presents the top level system design parameters and Figure 2 presents the system schematic. As shown in Figure 2, the turbine compressor provides the pressurized air to the PSOFC generator (in this case three $600 \mathrm{kWe}$ modules). Pressurized natural gas is also delivered to the PSOFC generator where it first undergoes reformation to $\mathrm{H}_{2}$ and $\mathrm{CO}$ within the cell stack, 
and then is electrochemically reacted with oxygen ions from the pressurized air producing DC electricity and pressurized, high temperature exhaust gas. The exhaust gas is then directed to the turbine expander which drives the turbine and the AC generator. As shown in Table 2,60\% of the electrical power is produced by the PSOFC generator and $40 \%$ by the turbine generator. Therefore, a PSOFC generator costing $\$ 500$ per kWe of PSOFC output, costs only $\$ 300$ per kWe of total system output; similarly a gas turbine generator costing $\$ 800$ per $\mathrm{kWe}$ of turbine generator output, costs only $\$ 320$ per kWe of total system output.

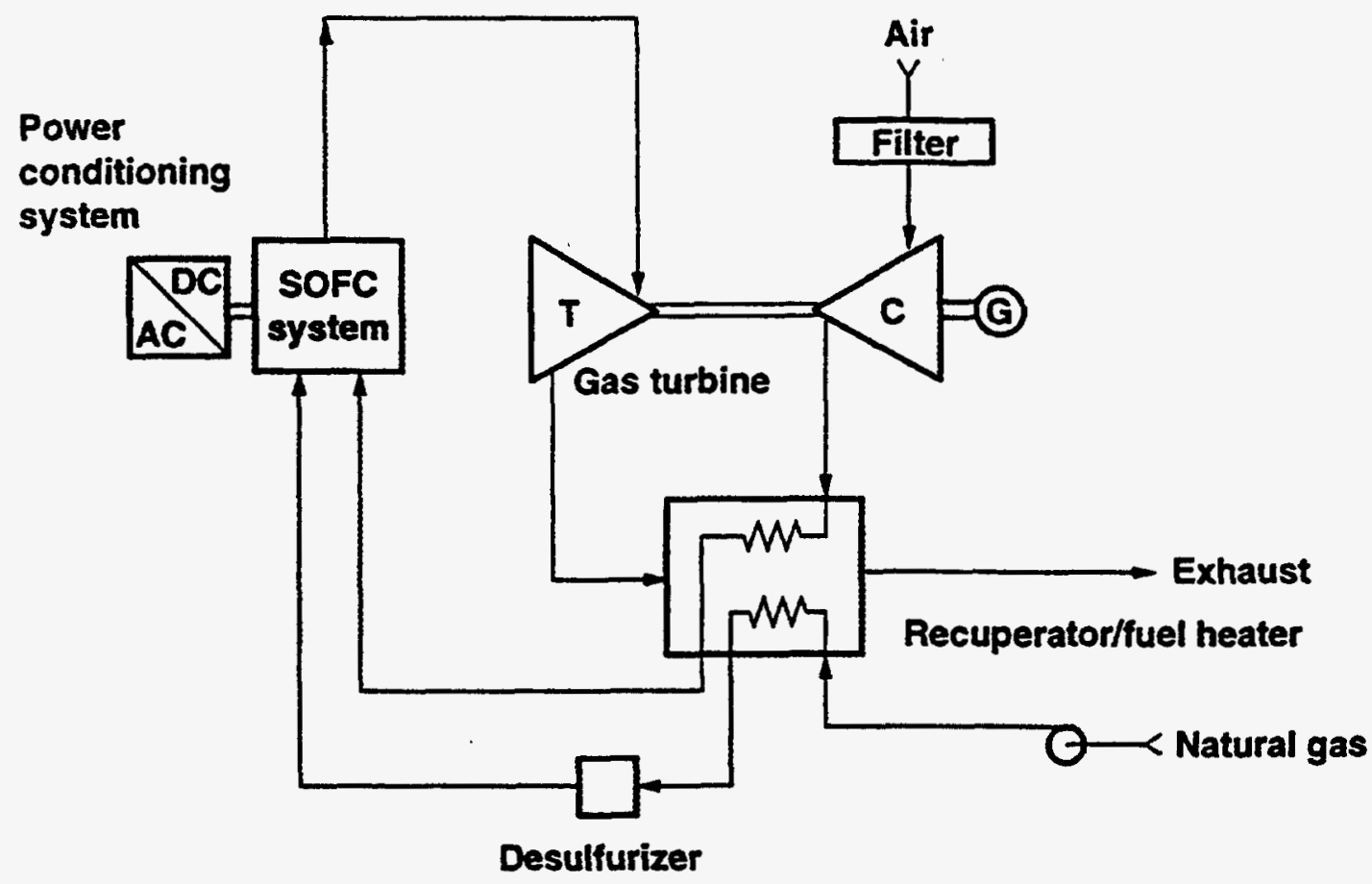

Fig. 2. $3 \mathrm{MWe}$ PSOFC/GT Power System Schematic 


\begin{tabular}{|l|c|}
\hline System Power Output (MWe AC) & 3.0 \\
\hline System Electrical Efficiency (AC/LHV, \%) & 63 \\
\hline PSOFC Power Output (MWe DC/AC) & $1.88 / 1.80$ \\
\hline GT Power Output (MWe AC) & 1.2 \\
\hline GT Pressure Ratio & $6: 1$ \\
\hline Number of PSOFC Modules & 3 \\
\hline PSOFC Module Output (MWe DC/AC) & $0.63 / 0.60$ \\
\hline Number of Cells per Module & 2496 \\
\hline Cell Diameter (cm) & 2.2 \\
\hline Cell Active Length (cm) & 150 \\
\hline Cell Power Output @ 6 atm (watts DC) & 250 \\
\hline
\end{tabular}

Table 2. 3 MWe PSOFC/GT Power System Design Parameters

Westinghouse intends to commercialize PSOFC/GT power systems initially in the power range $500 \mathrm{kWe}$ to $5 \mathrm{MWe}$ because of its unique advantages. Most significantly, such combined cycle systems can achieve electrical efficiencies in the range $62.72 \%$ unmatched by any other technology especially in the above power range. This is a direct result of the synergism between PSOFC technology and gas turbine technology. The PSOFC generator basically replaces the turbine combustor function during steady state operation because its exhaust gas temperature $\left(850^{\circ} \mathrm{C}\right.$ or $1560^{\circ} \mathrm{F}$ ) is a very acceptable turbine inlet temperature. In addition, pressurization significantly enhances cell performance (e.g., cell power output increases from 210 watts@ 1 atm to 250 watts@ 6 atm), resulting in reduced stack cost on a $\$ \mathbb{k W e}$ basis. 


\section{4. $3 \mathrm{MWe}$ PSOFC/GT Power System Cost Study}

\subsection{Commercial Manufacturing Facility}

As part of the commercialization plan for SOFC, a Commercial Manufacturing Facility (CMF) was sized and a conceptual design was performed. The CMF design consists of three duplicate production lines, each with an annual capacity of 100 MWe of SOFCs ( 150 MWe of systems) assuming 3 shifts per day and 330 production days per year. The process flow diagram shown in Figure 3, the "1997 AES Type" cell as specified in Table 1, and the above production rates are the basis for the CMF manufacturing equipment selection and sizing. The manufacturing equipment cost estimates were based upon quotations from equipment suppliers and scale-up of known PMF equipment costs accounting for size and cost savings associated with the purchase of multiple machines. In addition, no credit was taken for ongoing work to reduce the capital cost of the EVD process while maintaining its high levels of product quality and equipment reliability. The equipment costs for the first $100 \mathrm{MWe}$ per year cell production line was estimated at $\$ 45$ million while the second and third production lines were estimated at \$40 million each. 
-9 .

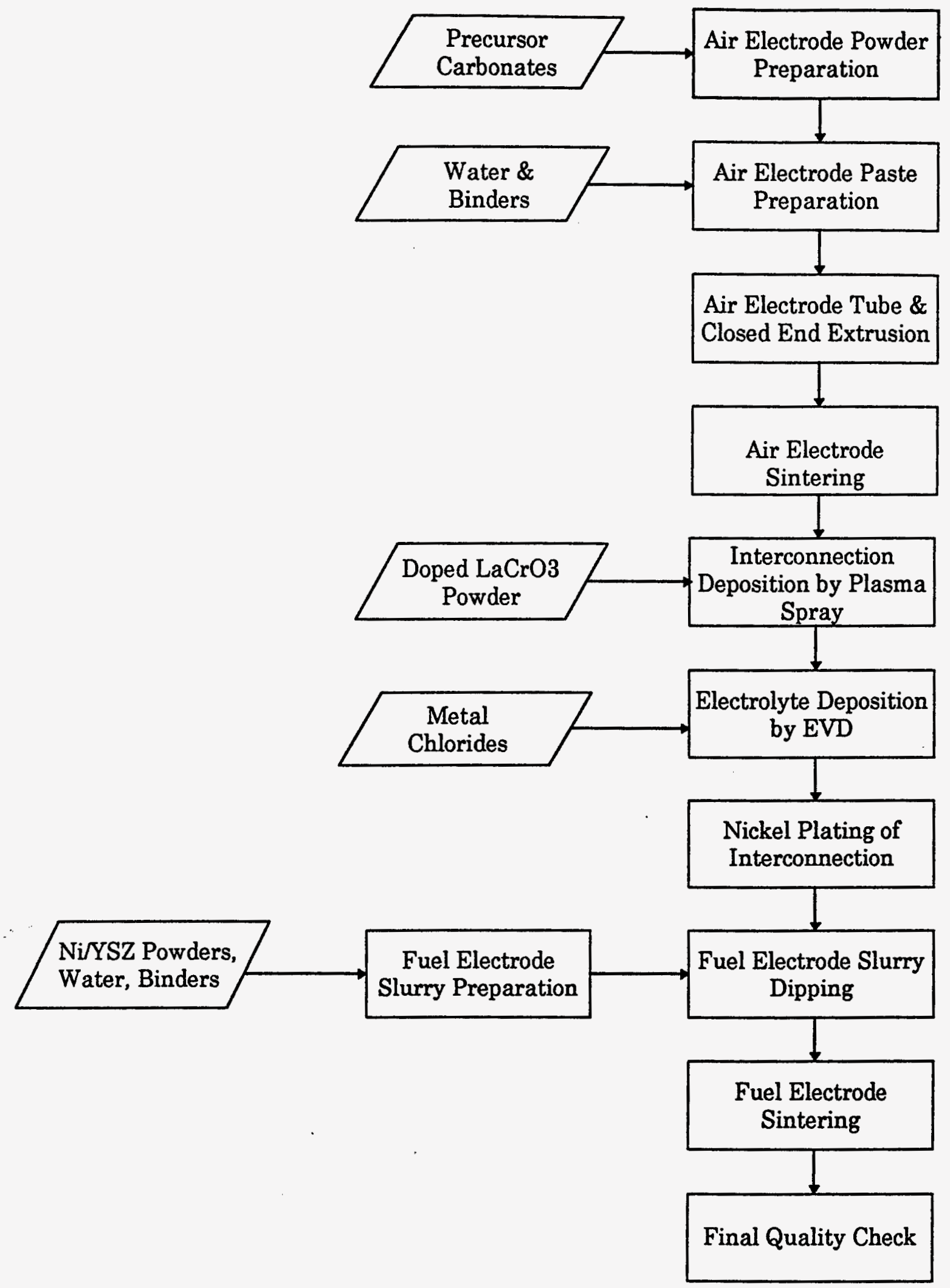

Fig. 3 SOFC Process Flow Diagram. 
In order to determine the building size, a layout of the three cell production lines was performed. In addition, space was allocated for SOFC module assembly and system assembly assuming the output of the CMF to be skid-mounted, fully packaged 3 MWe PSOFC/GT Power Systems requiring a minimum of site installation. The cost of the manufacturing building and property was estimated assuming both new construction and the purchase of an existing building. It was concluded that utilizing an existing building was advantageous to minimize the initial capital investment for the CMF as well as take advantage of an abundance of vacant sites. Preliminary estimates require approximately $250,000 \mathrm{ft}^{2}$ of $35 \mathrm{ft}$ high bay space per production line of $150 \mathrm{MWe}$ per year of $3 \mathrm{MWe}$ power systems for a total floor space of $750,000 \mathrm{ft}^{2}$. The building purchase price for an existing building of this size was estimated at $\$ 45$ per $\mathrm{ft}^{2}$ or $\$ 35$ million.

For the purpose of this cost study, a capital investment of $\$ 80$ million ( $\$ 45$ million for the first production line and $\$ 35$ million for the building) was used for an annual production rate of $150 \mathrm{MWe}$ of $3 \mathrm{MWe} \mathrm{PSOFC/GT}$ power systems. The manufacturing equipment was depreciated over 10 years and the building was depreciated over 20 years. These annual costs were included as part of the cell manufacturing cost discussed in Section 4.3.

In 1998, Westinghouse plans to perform a detailed design and cost estimate of the CMF as input to the decision making process in 1999 concerning construction of the CMF. Assuming a positive decision to proceed with the construction of the CMF, plant commissioning should occur in the year 2001. 


\subsection{Cell Manufacturing Process Description}

\subsubsection{Air Electrode Fabrication}

Air electrodes, which form the basic building block of the tubular SOFC, are manufactured from a mixture of base carbonates which form the doped $\mathrm{LaMnO}_{3}$ giving the cell its excellent durability, thermal cycle ability, and electrical performance. The base carbonates are first weighed and ball milled and subsequently calcined to provide a homogeneous material. The calcined material is then crushed and milled to provide the correct particle size distribution. This material is then mixed with water and binders to form a paste capable of being extruded. The paste is first extruded into a hemispherical mold to form the closed end of the tube, the mold removed, and the extrusion continues in a smooth fashion allowing for the formation of the remaining cylindrical section with a finished length of $181 \mathrm{~cm}$. Through this technique the closed end and cylinder remain a homogeneous material significantly improving quality and yield of the finished product. The extruded tube section is then sintered at approximately $1500^{\circ} \mathrm{C}$ to form the tubular building block.

\subsubsection{Interconnection Deposition by Plasma Spray}

The interconnection is deposited on the air electrode tube using an atmospheric plasma spray process to obtain a gas tight positive (t) contact stable in a dual atmosphere. The interconnection material is a doped $\mathrm{LaCrO}_{3}$ made from base carbonates much in the same manner as the air electrode powder. The powder is fed to a plasma spray gun where in combination with hydrogen and electricity, a plasma 
is formed which is sprayed onto the air electrode tube through a $150 \mathrm{~cm}$ by $1.1 \mathrm{~cm}$ window defined by a metal mask. The cell is held vertically while the gun traverses axially. Application requires approximately 4 minutes and lends itself well to automation through the use of multiple guns. This material and manufacturing process have been successfully demonstrated in two $25 \mathrm{kWe}$ generators of 576 cells each, which operated for greater than 5,000 and 13,000 hours, respectively. No significant voltage degradation was observed in either generator and the tests were ended because all the contractual commitments were fully satisfied.

\subsubsection{Electrolyte Deposition by Electrochemical Vapor Deposition}

To deposit a perfectly gas tight uniform layer over greater than $1000 \mathrm{~cm}^{2}$ with an exceptionally high yield, the Westinghouse design has relied on the electrochemical vapor deposition (EVD) process. At temperatures near $1200^{\circ} \mathrm{C}$ and vacuum pressures near $1 \mathrm{mmHg}$, anhydrous mixtures of yttrium trichloride and zirconium tetrachloride are sublimed and passed over the exterior of the air electrodeinterconnection assembly. Oxgen is provided to the tube interior. The chlorides react chemically and electrochemically with the oxygen passing through the tube wall to form the zirconium oxide layer on the tube exterior. Since the film growth is partially governed by the mixed conductivity of the material and electrical path resistance, thin portions grow faster than thicker portions resulting in a uniform film of nominally $40 \mu \mathrm{m}$ in thickness. 


\subsubsection{Application of a Nickel Contact by Electroplating}

The other advantage of the Westinghouse tubular SOFC besides its seal-less design is the metallic connections made between cells through the use of nickel felt or nickel wool. This electrical integration is made possible by nickel electroplating of the interconnection to provide the metallic surface for nickel felt bonding. Cells are placed in a nickel sulfamate bath containing a sacrificial nickel anode while a cathode is inserted into the cell tube. Since yttria stabilized zirconia (YSZ) is an insulator at room temperature, only the doped $\mathrm{LaCrO}_{3}$ material will carry electricity thereby defining its own mask. Current is passed through the system resulting in a 5.10 $\mu \mathrm{m}$ thick nickel layer on the interconnection. Both capital and material cost are small. A reliable contact has been achieved on all generators used in the field to date.

\subsubsection{Fuel Electrode Application by Slurry Dipping}

The fuel electrode, or anode, of the cell is deposited through a slurry dip process. A mixture of nickel and yttria stabilized zirconia (YSZ) powders having the proper thermal expansion match with the rest of the cell components is first blended and the mixed with water and binders in the proper ratio to achieve a highly viscous slurry. The material is then circulated through a number of vertical 2 inch diameter, 70 inch long acrylic tubes with a diaphragm pump to a void slurry

stratification. Cells from electrolyte EVD have a vinyl tape placed over the interconnection and are dipped in the slurry containers. Cells are then extracted at a slow rate allowing for flash drying to avoid slurry sagging which results in 
excessive thickness non-uniformities adversely impacting cell performance and structural integrity. Through this process a uniform $100 \mu \mathrm{m}$ thick layer can be maintained with a standard deviation of less than $10 \mu \mathrm{m}$. The vinyl tape is subsequently removed and the cell is prepared for the sinter step. This slurry application process has been utilized in the previous and the present Westinghouse manufacturing facility for both 50 and $150 \mathrm{~cm}$ active length cells with high reliability, high yield, and low material waste. With only ball mills and small pumps, the capital cost component and plant footprint requirement are minimal.

\subsubsection{Fuel Electrode Sintering}

To complete the fuel electrode application step the cell is sintered at approximately $1300^{\circ} \mathrm{C}$ in a dual atmosphere furnace for two hours. During this process air is delivered to the cell interior while a reducing atmosphere is provided on the fuel electrode side to avoid nickel oxidation. In a high volume facility a continuous furnace system would be utilized to decrease capital and operational costs. Fuel electrodes sintered in this manner have been shown to have the same or better performance then the EVD applied fuel electrode and have been thermal cycled from operating temperature $\left(1000^{\circ} \mathrm{C}\right)$ to room temperature over 30 times with no deleterious impact.

\subsection{Cell Manufacturing Cost}

Table 3 shows the breakdown of cell costs in 1997 dollars based upon materials, labor, capital depreciation, and CMF maintenance costs. Capital equipment was depreciated over a ten year period and the building cost was depreciated over twenty 
years. Even though the building was sized and costed for 3 production lines or $450 \mathrm{MWe} / \mathrm{year}$ of system capacity, the entire depreciation for the building was included in the cell cost for the first production line (under the capital column of Table 3), which burdened the cell cost by an extra $\$ 3 /$ cell. The material costs are based upon supplier quotations for large volumes equivalent to $100 \mathrm{MWe}$ of SOFCs per year. Labor and maintenance costs are based upon extrapolations from our PMF experience.

\begin{tabular}{|c|c|c|c|c|c|}
\hline Process Step & $\begin{array}{l}\text { Material } \\
\text { (\$/cell) }\end{array}$ & $\begin{array}{l}\text { Labor } \\
\text { (\$/cell) }\end{array}$ & $\begin{array}{l}\text { Capital } \\
\text { (\$/cell) }\end{array}$ & $\begin{array}{l}\text { Maintenance } \\
\text { (\$/cell) }\end{array}$ & $\begin{array}{l}\text { Total } \\
\text { (\$/cell) }\end{array}$ \\
\hline Air Electrode & 5.97 & 2.28 & 2.08 & 0.27 & 10.60 \\
\hline Interconnection & 0.21 & 0.75 & 1.47 & 0.15 & 2.58 \\
\hline Electrolyte & 9.28 & 5.94 & 7.91 & 2.95 & 26.08 \\
\hline Nickel Contact & 0.45 & 1.22 & 0.96 & 0.01 & 2.64 \\
\hline Fuel Electrode & 2.39 & 5.66 & 3.22 & 0.64 & 11.91 \\
\hline Total & 18.30 & 15.85 & 15.64 & 4.02 & 53.81 \\
\hline
\end{tabular}

Table 3. Breakdown of Cell Cost.

As seen in Table 3 the cell cost in large volume is only $\$ 53.81$ or $\$ 224$ per $\mathrm{kWe}$ of SOFC output ( $=\$ 53.81 /$ cell $\times 3 \times 2496$ cells $\div 1800 \mathrm{kWe})$. On a total system output basis this reduces to $\$ 134 / \mathrm{kW}(=224 \times .60)$. As expected, the electrolyte is the highest cost layer. Interestingly, the fuel electrode has the second highest cost at slightly less than half the cost of electrolyte. A simple comparison of the electrolyte and fuel electrode costs shows that the elimination of an EVD step in favor of a sintering step reduces the cell cost by approximately $\$ 14$ ( the four cost categories of EVD are comparable whether for electrolyte or fuel electrode). Therefore, changing 
the electrolyte deposition process from EVD to sintering would save $\$ 14 / \mathrm{cell}$ if a sintered electrolyte could provide the electrical performance and process yield of an electrolyte EVD process.

\subsection{PSOFC Generator Manufacturing Cost}

For the purpose of this cost study, a conceptual design was performed of a $1.8 \mathrm{MWe}$ PSOFC generator, consisting of three, $600 \mathrm{kWe}$ modules contained within a common pressure vessel as illustrated in Figure 4. Each module consists of 2496 SOFCs arranged in 26 bundle rows, each consisting of 96 cells, as shown in Figures 5 and 6 , 16 air plenum assemblies which include 2496 alumina air feed tubes, 24 stack reformer sections which are sandwiched between bundle rows, 1 spent fuel recirculation loop and pre-reformer, insulation, instrumentation, and 1 stack container. Finished cells are assembled into bundle rows with the use of nickel felts and nickel paste. The stack is then assembled by arranging the bundle rows and stack reformer sections in an alternating pattern on a support board assembly which also distributes the reformed fuel to each cell. The spent fuel recirculation loop and the air plenum assemblies are then installed. The stack is then surrounded by insulation and inserted into the stack container completing the $600 \mathrm{kWe}$ module assembly. Three of these modules are inserted into the pressure vessel as shown in Figure 4 forming the 1.8 MWe PSOFC generator. 
$-17-$

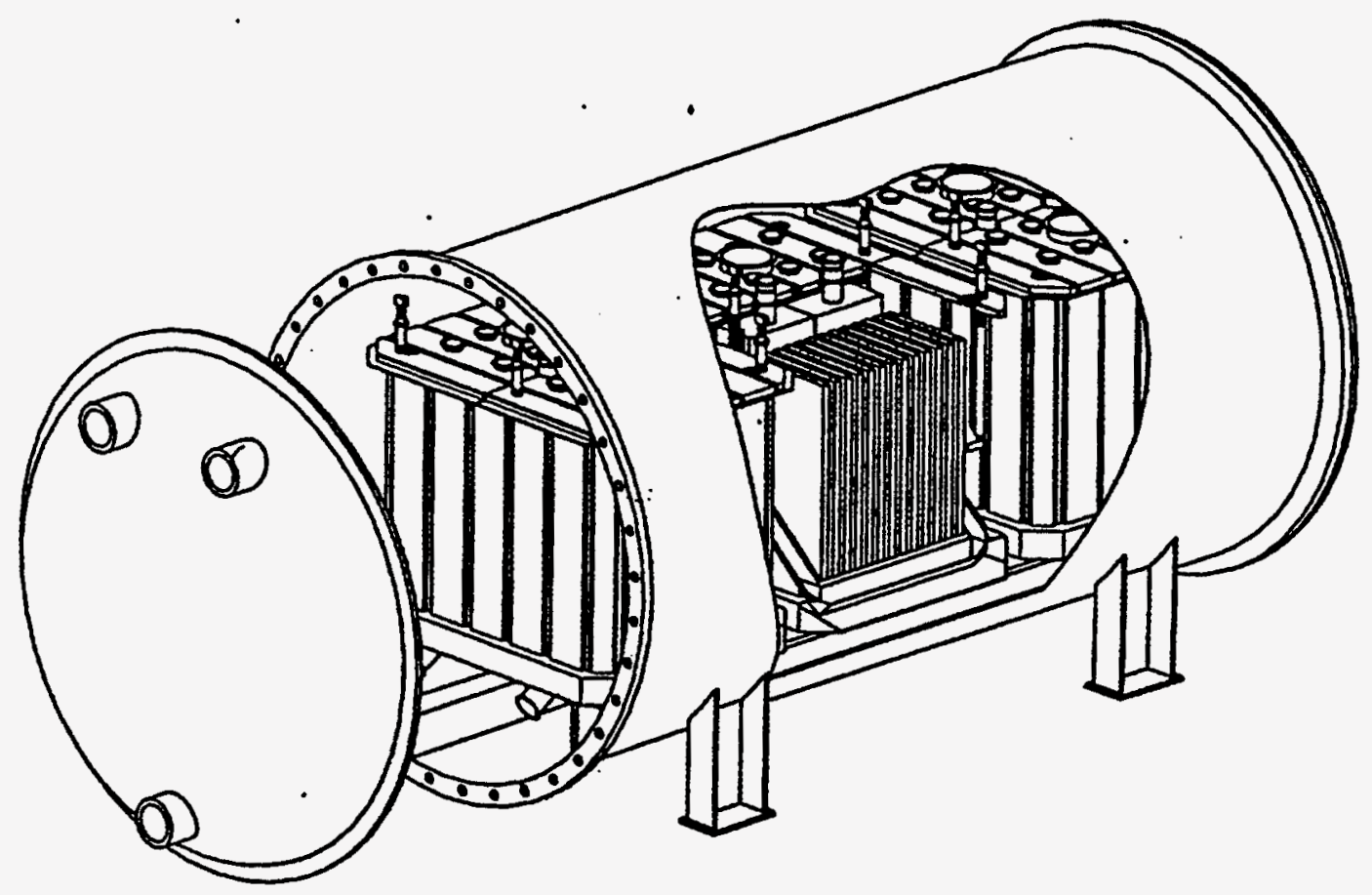

Fig. $41.8 \mathrm{MWe}$ PSOFC Generator 
$-18-$
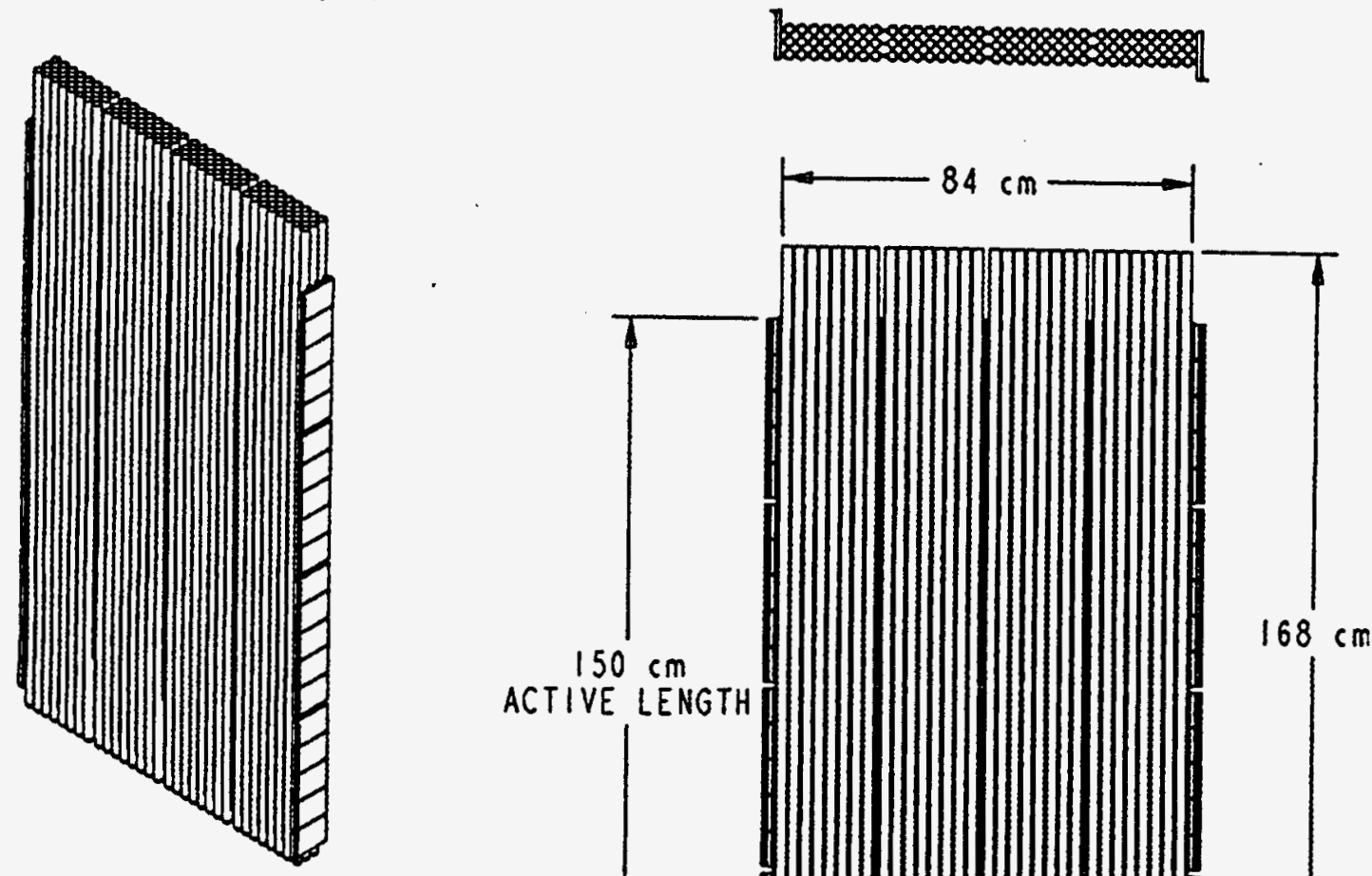

$150 \mathrm{~cm}$

ACTIVE LENGTH

CELLS PER BUNDLE:

CELLS PER BUNDLE-ROW: 96

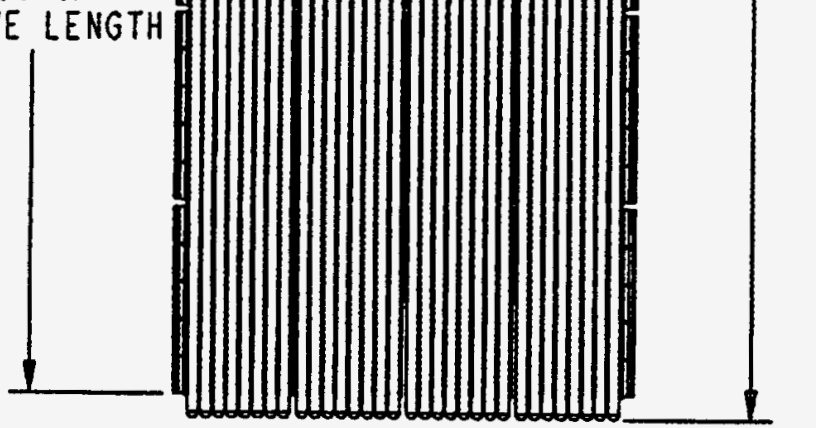

Fig. 5 Cell Bundle Row 


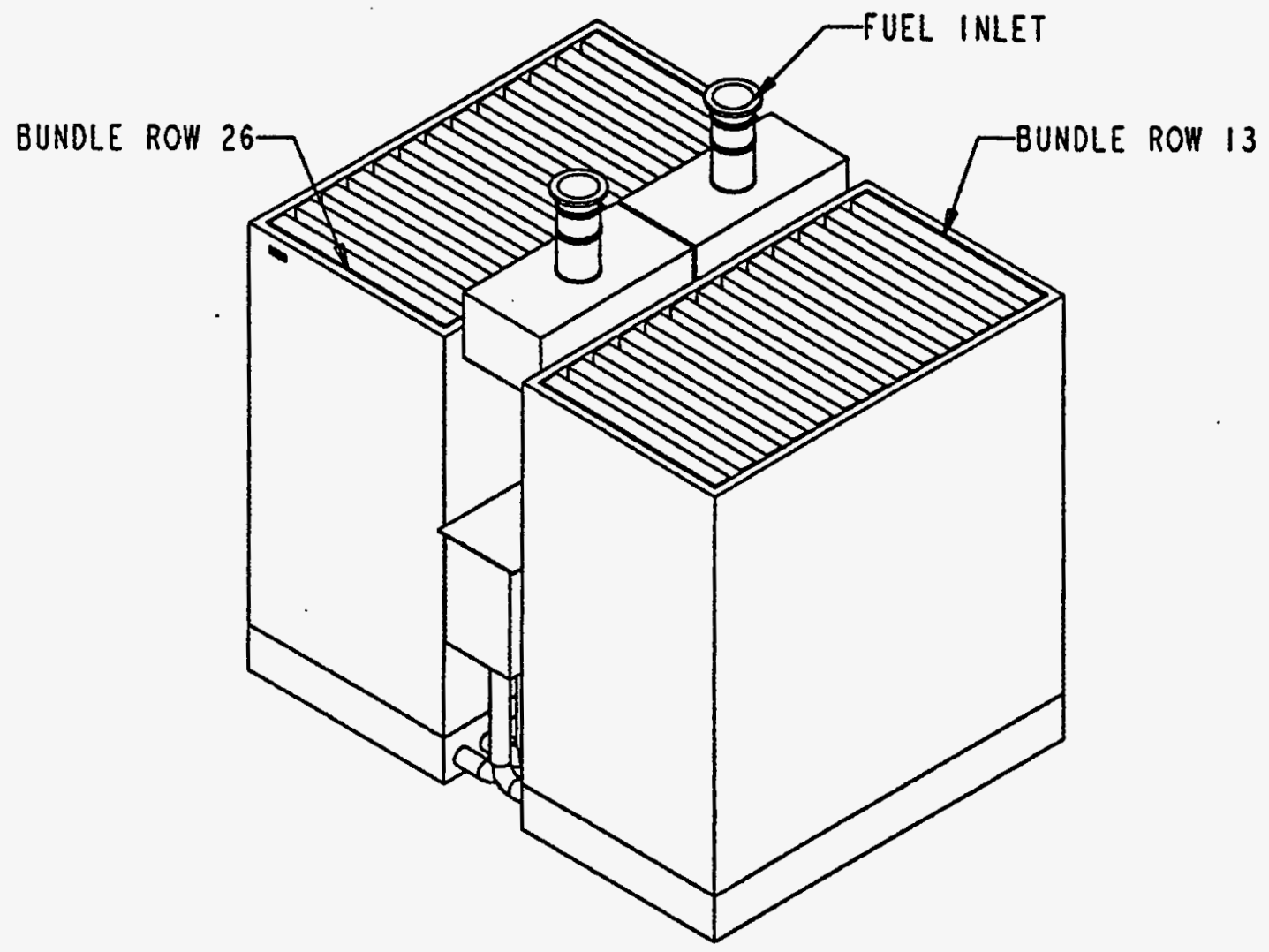

Fig. $6600 \mathrm{kWe}$ Cell Stack

The results of the 1.8 MWe PSOFC generator cost study are given in Table 4. The cost of each component in Table 4 was determined either 1 ) from quotations by suppliers (e.g., for pressure vessel) or 2) by cost buildup studies of material costs, machining costs, and assembly costs. The cost for "Cell Bundle Rows" includes the cell cost from Section 4.3 plus the value added in going from finished cells to bundle rows. It is important to remember that the total cost of $\$ 539 / \mathrm{kWe}$ (SOFC) is the cost per $\mathrm{kW}$ of SOFC output only and does not consider the turbine generator output. The PSOFC generator cost per $\mathrm{kW}$ of system output equals $60 \%$ of 539 or $\$ 323 / \mathrm{kW}$ (SYS). 


\begin{tabular}{|l|c|}
\hline \multicolumn{1}{|c|}{ Item } & \$kWe (SOFC) \\
\hline Cell Bundle Rows & 246 \\
\hline Pressure Vessel and Insulation & 166 \\
\hline Stack Insulation & 49 \\
\hline Stack Reformers & 33 \\
\hline Support Board Assembly & 18 \\
\hline Air Plenum Assemblies & 18 \\
\hline Stack Container & 7 \\
\hline Recirculation Loop Total & 2 \\
\hline \multicolumn{2}{|c|}{ Tota } \\
\hline
\end{tabular}

Table 4 1.8 MWe PSOFC Generator Cost Estimate

\subsection{PSOFC/GT Power System Cost}

The mature installed cost to the customer for a $3 \mathrm{MWe}$ PSOFC/GT Power System is the sum of the PSOFC generator cost (Section 4.4), the balance-of-plant equipment and packaging cost, shipping and site installation cost, and the appropriate markup of these costs to account for supplier's indirect costs and profit. The balance-of-plant is divided into a number of systems:

- Thermal Management System which consists of the gas turbine-generator, recuperator, piping and valves, startup air heater, and skid and enclosure;

- Fuel Supply System which consists of the natural gas desulfurization and delivery system, the purge gas system, and skid and enclosure;

- Instrumentation \& Control;

- Power Conditioning System which consists of the DC buss, DC-to-AC inverter, the AC switchgear, and skid and enclosure; and 
- Electrical Distribution System which distributes electrical power to equipment within the system (e.g., valve actuators, instruments, control computer, etc.)

Table 5 presents the results of the system cost study. The recuperated turbinegenerator subsystem is the major cost item under the Thermal Management System. Cost estimates from small gas turbine manufacturers range from $\$ 600$ to $\$ 800$ per $\mathrm{kWe}$ of T-G output. Since the T-G output is only $40 \%$ of the total system output, the cost of the turbine-generator subsystem should not exceed $\$ 320$ per kWe of system output $(=800 \times 0.4)$, which constitutes $89 \%$ of the cost of the Thermal Management System.

\begin{tabular}{|c|c|}
\hline Item & $\$ / \mathrm{kWe}$ (SYS) \\
\hline PSOFC Generator & 323 \\
\hline Thermal Management System & 360 \\
\hline Fuel Supply System & 15 \\
\hline Instrumentation \& Control & 30 \\
\hline Power Conditioning System & 110 \\
\hline Électrical Distribution System & 10 \\
\hline Sub-Total & 848 \\
\hline Shipping \& Installation & 130 \\
\hline Sub-Total & 978 \\
\hline Total Installed Cost (Including 30\% Markup) & 1271 \\
\hline
\end{tabular}

Table 5. 3 MWe PSOFC/GT Power System Cost Estimate

The conclusion of this cost study is that in large volume production (e.g., $>50$ units per year), a turnkey price (in 1997 dollars) of $\$ 1300 / \mathrm{kWe}$ (SYS) for a $3 \mathrm{MWe}$ 
PSOFC/GT Power System should be readily achievable with attractive margins remaining for the supplier.

\section{Cost of Electricity Analysis}

A cost of electricity (COE) analysis was performed comparing the COE of the $3 \mathrm{MWe}$ PSOFC/GT Power System with that of the most advanced small gas turbine generator system. The latter system called the Advanced Turbine System or ATS is currently under development in the United States and has a target turbine inlet temperature of $2200^{\circ} \mathrm{F}$. This ATS has a power output of about $4 \mathrm{MWe}$, a projected electrical efficiency of $42 \%$, and a projected total installed cost of about $\$ 800 / \mathrm{kWe}$. For comparison, the PSOFC/GT system described herein has a power output of $3 \mathrm{MWe}$, a projected electrical efficiency of $63 \%$, and a projected total installed cost of $\$ 1300 / \mathrm{kWe}$. The major COE assumptions are 1) a $15 \%$ capital charge rate, 2) \$3/MBTU natural gas cost, a plant capacity factor of $85 \%$ and 4) replacement of SOFC bundle rows every 10 years at a cost in 1997 dollars of $\$ 250 / \mathrm{kWe}$ (SOFC). The $\mathrm{COE}$ analyses resulted in the same $\mathrm{COE}$ (within 1\%) for both systems (4.8 cents/kWh). The relatively high capital cost of the PSOFC/GT system is offset by its relatively low fuel cost. For conservatism, a high capital charge rate and low natural gas cost were used in this analysis, which favor the economics of the ATS. Under expected conditions of lower capital charge rates and/or higher natural gas costs, the PSOFC/GT system would have a lower COE relative to the 4 MWe ATS.

\section{Summary and Conclusions}

The PSOFC/GT Power System is the most fuel efficient electrical power generation system ever conceived with efficiencies in the range $62-72 \%$ depending upon the 
ratio of SOFC-to-GT power output, and the type of GT selected. The broad application of this technology will significantly extend the use of our fossil fuel resources. For a $3 \mathrm{MWe}$ PSOFC/GT Power System with an electrical efficiency of $63 \%$, a total installed cost of $\$ 1300 / \mathrm{kWe}$ should be readily achievable after 2 to 3 years of commercial production. The projected cost of electricity (COE) for this machine compares very favorably with the projected $\mathrm{COE}$ for the most advanced small gas turbine system (ATS), which is also under development. In addition, the PSOFC/GT power system offers lower $\mathrm{CO}_{2}$ emissions by virtue of its higher efficiency ( $33 \%$ less $\mathrm{CO}_{2}$ emitted per $\mathrm{kWh}$ compared to the small ATS), $\mathrm{NO}_{\mathbf{x}}$ emissions of about $1 \mathrm{ppm}$ compared to $>10 \mathrm{ppm}$ for the ATS, and no $\mathrm{SO}_{\mathrm{x}}$ emissions since sulfur compounds are removed from the natural gas. 


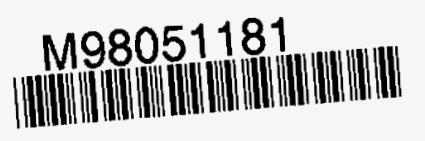

Report Number (14) DOE/FETC/C- $-98 / 7293$
CONF-9709197--

Publ. Date (11) $\frac{1997 / 1}{\text { Sponsor Code (18) }}$ UC Category (19) UC-1O1, DOE/ER 